\title{
Gallbladder Clear Cell Adenocarcinoma
}

National Cancer Institute

\section{Source}

National Cancer Institute. Gallbladder Clear Cell Adenocarcinoma. NCI Thesaurus. Code C43605.

A rare morphologic variant of gallbladder adenocarcinoma composed of malignant glandular epithelium with a predominance of glycogen rich clear cells. The cells display hyperchromic nuclei and well-defined cytoplasmic borders. 